\title{
TRANSLATION AND ADAPTATION OF THE BATES-JENSEN WOUND ASSESSMENT TOOL FOR THE BRAZILIAN CULTURE
}

\author{
Daniela Fernanda dos Santos Alves', Angélica Olivetto de Almeida², Juliany Lino Gomes Silva3, Flávia \\ Inglezina Morais ${ }^{4}$, Sônia Regina Pérez Evangelista Dantas ${ }^{5}$, Neusa Maria Costa Alexandre ${ }^{6}$
}

\footnotetext{
${ }^{1}$ Doctoral student, Programa de Pós-Graduação, Faculdade de Enfermagem, Universidade Estadual de Campinas (UNICAMP), Campinas, São Paulo, Brazil. E-mail: danny.fer@terra.com.br

${ }^{2}$ M.Sc. in Nursing, Nurse, Hospital de Clínicas UNICAMP. Campinas, São Paulo, Brazil. E-mail: angelicaolivetto@yahoo.com.br

${ }^{3}$ Master's student, Programa de Pós-Graduação, Faculdade de Enfermagem, UNICAMP. Campinas, São Paulo, Brazil. E-mail: julianylg@hotmail.com

${ }^{4}$ Stomatherapy Nurse, Hospital de Clínicas UNICAMP. Campinas, São Paulo, Brazil. E-mail: flavinha_solmorais@yahoo.com.br

${ }^{5}$ Ph.D. in Nursing, Professor Curso de Especialização em Estomaterapia, Faculdade de Enfermagem UNICAMP. Campinas, São Paulo, Brazil. E-mail: srpedantas@gmail.com

${ }^{6}$ Full Professor, Associate Professor Faculdade de Enfermagem UNICAMP. Campinas, São Paulo, Brazil. E-mail: nmca@unicamp.br
}

\begin{abstract}
Methodological study aimed at translating and adapting The Bates-Jensen Wound Assessment Tool for the Brazilian culture, through five stages: translation, synthesis, back translation, review by an expert panel, and, testing of the translated version. The Portuguese version was evaluated by 28 nurses who tested the understanding and practicality of the items. The expert panel evaluated the equivalence between the original and translated versions, resulting in concordance lower than $80 \%$ for seven items of the General Guidelines, which were modified. In the instrument, 13 items obtained a concordance rate exceeding $80 \%$, except for Wound Status Continuum, which achieved $40 \%$. Testing the translated version indicated good practicality. The Bates-Jensen Wound Assessment Tool is available in Brazil for research and use in clinical practice. Reliability and validity testing should be considered in future studies.

DESCRIPTORS: Translation. Nursing, methodology research. Wound healing. Nursing assessment.
\end{abstract}

\section{TRADUÇÃO E ADAPTAÇÃO DO BATES-JENSEN WOUND ASSESSMENT TOOL PARA CULTURA BRASILEIRA}

RESUMO: Estudo metodológico com o objetivo de traduzir e adaptar o Bates-Jensen Wound Assessment Tool para a cultura brasileira, por meio de cinco etapas: tradução, síntese, retrotradução, avaliação por um comitê de especialistas e teste da versão traduzida. A versão em língua portuguesa foi avaliada por 28 enfermeiros que testaram a compreensão dos itens e a praticabilidade. O comitê de especialistas avaliou a equivalência entre as versões original e traduzida, resultando em concordância inferior a $80 \%$ para sete dos itens do guia de preenchimento, que foram modificados. No instrumento, os 13 itens obtiveram taxa de concordância igual ou superior a $80 \%$, exceto o item Registro de Avaliação da Ferida, que obteve $40 \%$. O teste da versão traduzida indicou boa praticabilidade. O Bates-Jensen Wound Assessment Tool está disponível no Brasil para utilização em pesquisas e na prática clínica. Testes de confiabilidade e validade devem ser considerados em estudos futuros.

DESCRITORES: Tradução. Pesquisa metodológica em enfermagem. Cicatrização. Avaliação em enfermagem.

\section{TRADUCCIÓN Y ADAPTACIÓN DE LA BATES-JENSEN WOUND ASSESSMENT TOOL PARA LA CULTURA BRASILEÑA}

RESUMEN: Estudio metodológico destinado a la traducción y la adaptación del Bates-Jensen Wound Assessment Tool para la cultura brasileña a través de cinco etapas: traducción, síntesis, retro-traducción, revisión por un panel de expertos y las pruebas de la versión traducida. La versión en portugués fue evaluada por 28 enfermeras que verificaron la comprensión de los elementos y la practicidad. El comité de especialistas evaluó la equivalencia entre las versiones originales y traducidas, lo que resulta en una menor concordancia del $80 \%$ para siete de los ítems de la guía, que posteriormente fueron modificados. En el instrumento, los 13 ítems obtuvieron una tasa de concordancia superior al 80\%, excepto para el ítem de la evaluación de la herida, que obtuvo el $40 \%$. La prueba de la versión pre-final demostró buena factibilidad. El Bates-Jensen Wound Assessment Tool está disponible en Brasil para su uso en la investigación y la práctica clínica. La fiabilidad y la validez de las pruebas deben ser consideradas en futuros estudios

DESCRIPTORES: Traducción. Investigación metodológica em enfermería. Cicatrización de heridas. Evaluación en enfermería. 


\section{INTRODUCTION}

Caring for patients with chronic wounds has been a major challenge in nursing clinical practice; resulting in high rates of morbidity and a significant impairment of quality of life. ${ }^{1}$ These injuries affect a large portion of the world's population, generating high costs for public health in many countries. $^{2}$

Wound assessment is one of the basic stages for care planning in all healthcare levels: ambulatory, home or hospital. International guidelines for wound treatment recommend a minimum of weekly evaluation, using a standardized instrument that enables monitoring of the healing process. However, there is not yet consensus on the best way to evaluate the wound and its healing process. ${ }^{3-5}$

The international literature offers instruments for evaluating wounds, including the: Pressure Sore Status Tool (PSST), ${ }^{6}$ Pressure Ulcer Scale for Healing (PUSH), ${ }^{7}$ Wound Healing Scale (WHS), ${ }^{8}$ Sussman Wound Healing Tool (SWHT), ${ }^{9}$ and Bates-Jensen Wound Assessment Tool (BWAT). ${ }^{10}$ These instruments are validated, reliable, aid clinical practice, and can be used as decision tools by nurses for patient care. ${ }^{1}$

Among the available instruments, the Pressure Sore Status Tool (PSST), developed in 1990, using the Delphi technique; aims to monitor the healing process of pressure ulcers. In 2001, the instrument was reformulated in order to be used for other wounds etiologies, and was renamed the Bates-Jensen Wound Assessment Tool (BWAT). ${ }^{3}$

The current version of the BWAT contains 13 items assessing size, depth, edges, undermining, type and amount of necrotic tissue, type and amount of exudate, peripheral tissue edema and induration, skin color surrounding wound, granulation tissue, and epithelialization. The measuring scale is a five point Likert types, where 1 indicates the best condition of the wound and 5 , the worst condition. The total score is obtained as the sum of all the items, and can range from 13 to 65 points, with higher scores indicating the worst wound conditions. Items such as size, depth, edges and detachment should be scored as zero when the lesions are healed. The instrument contains two additional items - location and shape - which are not part of the total score. ${ }^{10}$
In its original format, a guide accompanies the BWAT with instructions for completion of each assessment of the wound items. This guide enables professionals to use the same criteria during the evaluation process, as it defines each characteristic to be observed. The BWAT has satisfactory validity and reliability indices, with a Cronbach's alpha of 0.90 , sensitivity of $61 \%$, specificity of $52 \%$, and a positive predictive value of $65 \% .^{10}$

Considering the recommendations from the main international consensus that guide the assessment of wound conditions through a reliable method, and the difficulty of nurses in clinical practice to assess and monitor the healing process of chronic wounds, this study aims to translate and adapt the Bates-Jensen Wound Assessment Tool instrument for the Brazilian culture, and to assess its feasibility.

\section{METHOD}

This was a methodological study, characterized by translation and adaptation of the BWAT to Brazilian culture, conducted after authorization from Bates-Jensen, the author of the original instrument.

The instrument and the completion guide were submitted for translation and a cultural adaptation procedure, in accordance with international recommendations, ${ }^{11-12}$ using the steps: translation, synthesis, back translation, evaluation by a committee of experts, and testing of the translated version. The purpose of these steps was to ensure the quality of the adapted instrument and its equivalence with the original instrument.

Two independent translators, a nurse and a language teacher, fluent in English and having Portuguese as their first language, performed the first BWAT translation; only the language teacher was informed of the study objectives. A third translator, fluent in the instrument's source language, which produced the synthesis version of the instrument, assessed the first two translations.

In the third step, the translation synthesis was sent to two other translators, a nurse and a language teacher who were fluent in the target language (Portuguese), with English as their first language, to produce back-translations. The purpose of this step was to evaluate discrepancies between the original and the translated instrument. 
The equivalence between the original and the translated BWAT versions was evaluated by a committee of five experts: a teacher with experience in the methodological process of translation and adaptation of instruments, a teacher with experience in caring for patients with wounds; two nurses and one generalist stomatherapy nurse. Committee members were invited to review the synthesis version according to its equivalence with the original version, indicating their agreement to each item and modifications necessary to adjust the item. For this procedure, experts received written guidance and a tool specifically developed for this analysis, also containing the original instrument and all versions produced.

The equivalence assessment was performed in a quantitative manner by individual responses of each of experts, for each of the items. The interrater agreement (IRR) was determined, expressed in percentage, calculated by: (number of experts who agreed with the item/number of experts) $x 100$. The items were appropriate when the IRR was less than $80 \% \cdot{ }^{13}$ Items with an IRR lower than $80 \%$ were modified in accordance with the committee's suggestions. The translated instrument was obtained after these steps, and named the BWAT Brazilian version

The translated version of the BWAT was tested by nurses in adult and intensive care patients of a teaching hospital in São Paulo state. Generalist nurses and specialists with professional experience of more than five years integrating patients with wounds within their institutional commission were invited.

For assessment of the translated instrument, nurses received a sociodemographic characterization form, the modified Feasibility Assessment Tool, and the translated version of the BWAT Brazilian version. The sociodemographic form consisted of seven items: unit, age, sex, length of experience as a nurse in the institution and sector, and nurse education.

The practicality of the BWAT Brazilian version was assessed using a modified Feasibility Assessment Tool. ${ }^{14}$ This instrument contains four items assessing the ease of understanding the instructions, items, completing the answers, and the interest in having a tool in clinical practice for evaluation of chronic wounds. All questions were evaluated using a five point Likert response scale: 1- strongly disagree, 2- partially disagree, 3- I have no opinion, 4- partially agree and 5- strongly agree. The analysis of responses was obtained by the percentage of response of participants for each of the items. The higher percentage of responses of "partially agree" and "agree", the greater the instrument feasibility. The BWAT Brazilian version modifications suggestions for the translated version were analyzed by the authors.

The study was registered in the Brazilian Platform (CAAE: 08662512.3.0000.5404) and approved by the Research Ethics Committee (Protocol n. 183 265, of 12.18.2012).

\section{RESULTS}

The translation and adaptation of the BWAT for the Brazilian culture followed the steps of translation, synthesis, back translation and testing of translated version. Translators did not report difficulties in producing versions of the instrument and completion guide.

Most items in the completion guide received an IRR lower than 80\%: general guidelines $(\mathrm{IRR}=60 \%)$, depth $(\mathrm{IRR}=60 \%)$, edges $(\mathrm{IRR}=60 \%)$, necrotic tissue type (IRR $=60 \%)$, peripheral tissue edema and induration (IRR $=60 \%$ ), granulation tissue $(\mathrm{IRR}=60 \%)$, and epithelialization (IRR=60\%). With regard to the instrument, most items received an IRR equal to or greater than $80 \%$, except for wound status continuum, which achieved an IRR $=40 \%$.

Because 13 items achieved an IRR below $80 \%$, a consensus reunion among experts was not necessary, as suggested modifications were specific and related to order and agreement between words. By consensus, the authors adjusted and formulated the final BWAT version according to suggestions of the experts. The words of the instrument that generated discrepancies between experts were modified with technical adequacy to the term of the English language, with semantic equivalence in respect to the original instrument in English. All experts agreed to maintain the layout and the original instrument name - Bates-Jensen Wound Assessment Tool (BWAT) - plus the term "Brazilian version", to facilitate international scientific access. The characteristics of the 28 participants in the testing of the translated version are shown in Table 1. 
Table 1 - Profile of nurse participants in the pre-test and translated version of the Bates-Jensen Wound Assessment Tool. Campinas-SP, Brazil, 2012

\begin{tabular}{lccccc}
\hline \multicolumn{1}{c}{ Variables } & $\mathbf{n}(\%)$ & Mean & Standard deviation & Minimal & Maximal \\
\hline Sex & & & & & \\
$\quad$ Female & $26(92,9)$ & & & & \\
$\quad$ Male & $2(7.1)$ & & & & \\
Age (years) & & 35.4 & 8.0 & & \\
Professional education & & & & \\
$\quad$ Specialization & $13(46.4)$ & & & & \\
Graduation & $9(32.1)$ & & & & \\
Masters degree & $5(17.9)$ & & & & \\
$\quad$ Professional Improvement course & $1(3.6)$ & & 8.8 & $<1$ year & 31 \\
Experience time (years) & & & & \\
$\quad$ In profession & & 10.4 & 4.6 & $<1$ year & 18 \\
In current unit & & 8.9 & 8.0 & $<1$ year & 28 \\
In current institution & & & & \\
\hline
\end{tabular}

Nurses who participated in the evaluation of the BWAT Brazilian version assessed the comprehension of items and the instrument completion guide. Participants reported difficulties with: completion of the shape, the location of the wound, mark on the body chart, the anatomical location of the lesion, and score wound status continuum. They also indicated the substitution of some terms and standardization of nomenclature, for example, replacing the term "round" with "circular".

Regarding feasibility, the BWAT Brazilian version had adequate feasibility according to the nurses, with most of answers of the four evaluation items marked as "partially agree" or "strongly agree" (Table 2).

Table 2 - Evaluation of the feasibility of the Bates-Jensen Wound Assessment Tool - Brazilian version, according to respondents. Campinas-SP,Braszil, 2012

\begin{tabular}{lccccc}
\hline Opinion of respondents & $\begin{array}{c}\text { Strongly } \\
\text { disagree }\end{array}$ & $\begin{array}{c}\text { Partially } \\
\text { disagree }\end{array}$ & $\begin{array}{c}\text { No opin- } \\
\text { ion }\end{array}$ & $\begin{array}{c}\text { Partially } \\
\text { agree }\end{array}$ & $\begin{array}{c}\text { Strongly } \\
\text { agree }\end{array}$ \\
\cline { 2 - 6 } & $\mathbf{n ~ ( \% )}$ & $\mathbf{n ~ ( \% )}$ & $\mathbf{n ~ ( \% )}$ & $\mathbf{n ~ ( \% )}$ & $\mathbf{n ~ ( \% )}$ \\
\hline $\begin{array}{l}\text { Instructions for completion were easy } \\
\text { to understand }\end{array}$ & - & - & - & $11(39.3)$ & $17(60.7)$ \\
$\begin{array}{l}\text { Survey questions were easy to under- } \\
\text { stand }\end{array}$ & - & $1(3.6)$ & - & $5(17.9)$ & $22(78.6)$ \\
$\begin{array}{l}\text { Questionnaire answers were easy to } \\
\text { indicate }\end{array}$ & - & $1(3.6)$ & - & $7(25.0)$ & $20(71.4)$ \\
$\begin{array}{l}\text { Support of an instrument to assess } \\
\text { wounds was interesting to have }\end{array}$ & - & - & - & $1(3.6)$ & $28(96.4)$ \\
\hline
\end{tabular}

After testing the translated version, the original instrument author was consulted for changes in the items location, shape and the body chart. All the nurses and authors suggestions were accepted by Dr. Bates-Jensen and incorporated into the translated instrument. After items modification, instructions to mark the body chart and wound status continuum, the BWAT advanced version was produced, translated and adapted to the Brazilian culture (Annex 1).

\section{DISCUSSION}

Accurate assessment of a chronic wound is essential for identification of conditions and ap- 
Alves DFS, Almeida AO, Silva JLG, Morais FI, Dantas SRPE, Alexandre NMC

propriate decisions regarding topical treatment. ${ }^{10,15}$ The use of validated and reliable instruments enables proper documentation and therapeutic indication, ${ }^{1,10}$ providing information exchange in the scientific community, and comparison of results in different countries. ${ }^{12}$ These instruments, when properly used, support intervention and treatment effectiveness. ${ }^{12}$

The BWAT was translated and proved to be a valid method for chronic wound assessment. ${ }^{10}$ Steps of instrument translation and adaptation were satisfactory and resulted in the BWAT Brazilian version, after adaptation to the Portuguese culture and language, as recommended in the literature for instruments developed in other languages and / or cultures. ${ }^{16}$ Replacement of terms and nomenclature standardization was performed, incorporating the author of original article in decisions regarding modification of the translated instrument.

Regarding the completion guide, agreement rates lower than $80 \%$ in eight items were found, determining specific changes suggested in the order and concordance of words. Studies show that an expert committee can modify guidelines and instrument format, changing and adding new items, ${ }^{12}$ and that agreement rates lower than $80 \%$ are relevant, determining changes in the instrument. ${ }^{13}$

The literature recommends that, for equivalency between the original and translated version, the expert committee should be composed of professionals with methodological experience in health and linguistics, who should evaluate the instrument according to the semantic, conceptual and idiomatic equivalences. ${ }^{11}$ This research followed all recommended steps in the literature, and modifications suggested by experts were punctual and accepted.

There are few reliable and valid instruments for assessing chronic wounds in Brazil, and instrument incorporation for this purpose facilitates decision making by nurses about treatment and follow up of patients with wound in clinical practice. ${ }^{4,15}$

\section{CONCLUSION}

The Bates-Jensen Wound Assessment Tool instrument was successfully translated and adapted to the Brazilian culture, following the literature recommendations, with good feasibility for use in clinical practice and research. Studies to verify validity and reliability of the BWAT Brazilian version are recommended.

\section{REFERENCES}

1. Mullins M, Thomason SS, Legro M. Monitoring pressure ulcer healing in persons with disabilities. Rehabil Nurs. 2005 May-Jun; 30(3):92-9.

2. Sen CK, Gordillo GM, Roy S, Kirsner R, Lambert L, Hunt TK, et al. Human skin wounds: a major and snowballing threat to public health and the economy. Wound Repar Regen. 2009 Nov-Dec; 17(6):763-71

3. Bates-Jensen B, Sussman C. Tools to measure wound healing. In Sussman C, Bates-Jensen B, editors. Wound Care, a Collaborative Practice Manual for Health Professionals, 4 ed. Baltimore (US): Lippincott Williams and Wilkins; 2012. p. 131-72.

4. Morais GFC, Oliveira SHS, Soares MJGO. Avaliação de feridas pelos enfermeiros de instituições hospitalares da rede pública. Texto Contexto Enferm. 2008 Jan-Mar; 17(1):98-105.

5. Santos VLCG, Azevedo MAJ, Silva TS, Carvalho VMJ, Carvalho VF. Adaptação transcultural do Pressure Ulcer Scale for Healing (PUSH) para a língua portuguesa. Rev Latino-Am Enfermagem. 2005 Mai-Jun; 13(3):305-13.

6. Pillen H, Miller M, Thomas J, Puckridge P, Sandison S, Spark JI. Assessment of wound healing: validity, reliability and sensitivity of available instruments. Wound Practic Res. 2009 Nov; 17(4):208-17.

7. Thomas DR, Rodeheaver GT, Bartolucci AA, Franz RA, Sussman C, Ferrell BA, et al. Pressure ulcer scale for healing: derivation and validation of the PUSH tool. The PUSH Task Force. Adv Wound Care. 1997 Sep; 10(5):96-101.

8. Krasner D. Wound healing scale, version 1.0: a proposal. Adv Wound Care. 1997 Sep; 10(5):82-5.

9. Sussman C, Swanson G. Utility of the Sussman Wound Healing Tool in predicting wound healing outcomes in physical therapy. Adv Wound Care. 1997 Sep; 10(5):71-7.

10. Harris C, Bates-Jensen B, Parslow N, Raizman R, Singh M, Ketchen R. Bates-Jensen Wound Assessment Tool: pictorial guide validation project. J Wound Ostomy Continence Nurs. 2010 May-Jun; 37(3):253-9.

11. Beaton D, Bombardier C, Guillemin F, Ferraz, MB. Recommendations for the Cross-Cultural adaptation of the DASH \& QuickDASH Outcome Measures. IWHO. 2007; 1(1):1-45.

12. Alexandre NMC, Guirardello EB. Adaptación cultural de instrumentos utilizados en salud ocupacional. Pan American Health Organization. 2002 Feb; 11(2):109-11. 
13. Pasquali L. Psicometria teoria dos testes na psicologia e na educação. Rio de Janeiro (RJ): Vozes; 2003.

14. Coluci MZO, Alexandre NMC. Development of a questionnaire to evaluate the usability of assessment instruments. Rev Enferm UERJ. 2009 Jul-Set; 17(3):378-82.
15. Beitz JM, Van Rijswijk. Using wound care algorithms: a content validation study. J Wound Ostomy Continence Nurs. 1999 Sep; 26(5):238-49.

16. Hunt SM, Alonso J, Bucquet D, Niero M, Wiklund I, McKenna S. Cross-cultural adaptation of health measures. Health Policy. 1991 Jun; 19: 33-44. 
APPENDIX 1

\section{BATES-JENSEN WOUND ASSESSMENT TOOL Versão Brasileira}

NOME:

ETIOLOGIA DA FERIDA:

Complete a folha de pontuação para avaliar as condiçoes da ferida. Avalie cada item escolhendo a resposta que melhor descreve a ferida. registrando as respectivas pontuaçðes e datas na coluna correspondente. Se a ferida estiver cicatrizada/resolvida, pontue os itens $1,2,3$ e 4 como zero.

Localizaçào: Circule a localizaçăo anatômica e identifique direito (D) ou esquuerdo (E). Sacro e cóccix

Trocânter

Tuberosidade isquiática
Maléolo lateral

Maléolo medial

Calcâneo
Outro Local

Forma: Padrōes gerais da ferida: avalie observando o perimetro e a profundidade. Circule a descrição apropriada e registre a data:

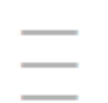

Irregular

Circular/oval

Quadrangular/Retangular

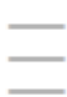

Linear ou alongada

Cỏncava

Formato de borboleta

Outro Formato

Nos diagramas corporais, assinale um " $\mathrm{X}$ " para marcar o local.

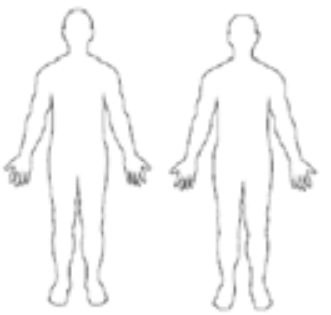

\begin{tabular}{|c|c|c|c|c|}
\hline Item & Avaliaçào & $\frac{1}{\text { Pontuaçào }}$ & $\frac{f}{-}-$ & Pontuaçào \\
\hline 1. Tamanho & $\begin{array}{l}1=\text { Comprimento } x \text { largura }<4 \mathrm{~cm}^{2} \\
2=\text { Comprimento } x \text { largura } 4-<16 \mathrm{~cm}^{2} \\
3=\text { Comprimento } x \text { largura } 16,1-<36 \mathrm{~cm}^{2} \\
4=\text { Comprimento } x \text { largura } 36,1-<80 \mathrm{~cm}^{2} \\
5=\text { Comprimento } x \text { largura }>80 \mathrm{~cm}^{2}\end{array}$ & & & \\
\hline $\begin{array}{c}2 . \\
\text { Profundidade }\end{array}$ & $\begin{aligned} 1= & \text { Eritema não branqueável na pele integra } \\
2= & \text { Perda parcial da espessura da pele envolvendo epiderme e/ou } \\
& \text { derme } \\
3= & \text { Perda total da espessura da pele envolvendo dano ou necrose do } \\
& \text { tecido subcutâneo; pode estender-se até a fáscia subjacente, mas } \\
& \text { sem ultrapassá-la; e/ou perda parcial e total e/ou camadas teciduais } \\
& \text { cobertas por tecido de granulação } \\
4= & \text { Coberto com necrose } \\
5= & \text { Perda total da espessura da pele com destruição extensa, necrose } \\
& \text { tecidual ou dano muscular. ósseo ou das estruturas de apoio }\end{aligned}$ & & & \\
\hline 3. Bordas & $\begin{aligned} 1= & \text { Indefinidas, não visiveis claramente } \\
2= & \text { Definidas, contomo claramente visivel, aderidas, niveladas com a } \\
& \text { base da ferida } \\
3= & \text { Bem definidas, não aderidas à base da ferida } \\
4= & \text { Bem definidas, não aderidas à base, enrolada, espessada } \\
5= & \text { Bem definidas, fibróticas, com crostas e/ou hiperqueratose }\end{aligned}$ & & & \\
\hline $\begin{array}{c}4 . \\
\text { Descolamento }\end{array}$ & $\begin{array}{l}1=\text { Ausente } \\
2=\text { Descolamento }<2 \mathrm{~cm} \text { em qualquer área } \\
3=\text { Descolamento de } 2-4 \mathrm{~cm} \text { envolvendo }<50 \% \text { das bordas da ferida } \\
4=\text { Descolamento de } 2-4 \mathrm{~cm} \text { envolvendo }>50 \% \text { das bordas da ferida } \\
5=\text { Descolamento }>4 \mathrm{~cm} \text { ou tunelização em qualquer área }\end{array}$ & & & \\
\hline $\begin{array}{l}\text { 5. Tipo de } \\
\text { tecido necrótico }\end{array}$ & $\begin{array}{l}1=\text { Ausente } \\
2=\text { Tecido não viável branco/cinza e/ou esfacelo amarelo não aderido } \\
3=\text { Esfacelo amarelo pouco aderido } \\
4=\text { Escara preta, úmida, aderida } \\
5=\text { Escara preta, dura, totalmente aderida }\end{array}$ & & & \\
\hline $\begin{array}{l}\text { 6. Quantidade } \\
\text { de tecido } \\
\text { necrótico }\end{array}$ & $\begin{array}{l}1=\text { Ausente } \\
2=<25 \% \text { do leito da ferida coberto } \\
3=25 \% \text { a } 50 \% \text { da ferida coberta } \\
4=>50 \% \text { e }<75 \% \text { da ferida coberta } \\
5=75 \% \text { a } 100 \% \text { da ferida coberta }\end{array}$ & & & \\
\hline
\end{tabular}

continued... 


\begin{tabular}{|c|c|c|c|c|}
\hline Item & Avaliaçào & $\frac{1}{\text { Pontuaçào }}$ & $\frac{1}{\text { Pontuaçào }}$ & $\frac{1}{\text { Pontuaçào }}$ \\
\hline $\begin{array}{l}\text { 7. Tipo de } \\
\text { exsudato }\end{array}$ & $\begin{aligned} 1= & \text { Ausente } \\
2= & \text { Sanguinolento } \\
3= & \text { Serossanguinolento: fino, aquoso, vermelho/rosa pálido } \\
4= & \text { Seroso: fino, limpido, aquoso } \\
5= & \text { Purulento: fino ou espesso, entre marrom opaco e amarelo, com ou } \\
& \text { sem odor }\end{aligned}$ & & & \\
\hline $\begin{array}{l}\text { 8. Quantidade } \\
\text { de exsudato }\end{array}$ & $\begin{array}{l}1=\text { Ausente, ferida seca } \\
2=\text { Escassa, ferida úmida, mas sem evidência de exsudato } \\
3=\text { Pequena } \\
4=\text { Moderada } \\
5=\text { Grande }\end{array}$ & & & \\
\hline $\begin{array}{l}\text { 9. Cor da pele } \\
\text { ao redor da } \\
\text { ferida }\end{array}$ & $\begin{array}{l}1 \text { = Rósea ou normal para o grupo étnico } \\
2=\text { Vermelha brilhante e/ou esbranquiçada ao toque } \\
3 \text { = Branca ou cinza pálido ou hipopigmentada } \\
4=\text { Vermelha escura ou roxo e/ou năo branqueável } \\
5 \text { = Preta ou hiperpigmentada }\end{array}$ & & & \\
\hline $\begin{array}{l}\text { 10. Edema do } \\
\text { tecido } \\
\text { periférico }\end{array}$ & $\begin{array}{l}1=\text { Sem edema } \\
2=\text { Edema não depressivel estende-se }<4 \mathrm{~cm} \text { ao redor da ferida } \\
3=\text { Edema năo depressivel }>4 \mathrm{~cm} \text { ao redor da ferida } \\
4=\text { Edema depressivel }<4 \mathrm{~cm} \text { ao redor da ferida } \\
5=\text { Crepitaçōes e } / \text { ou edema depressivel }>4 \mathrm{~cm} \text { ao redor da ferida }\end{array}$ & & & \\
\hline $\begin{array}{c}11 . \\
\text { Endurecimento } \\
\text { do tecido } \\
\text { periférico }\end{array}$ & $\begin{array}{l}1=\text { Ausente } \\
2=\text { Endurecimento }<2 \mathrm{~cm} \text { ao redor da ferida } \\
3=\text { Endurecimento } 2-4 \mathrm{~cm} \text { estendendo-se }<50 \% \text { ao redor da ferida } \\
4=\text { Endurecimento } 2-4 \mathrm{~cm} \text { estendendo-se }>50 \% \text { ao redor da ferida } \\
5=\text { Endurecimento }>4 \mathrm{~cm} \text { em qualquer área ao redor da ferida }\end{array}$ & & & \\
\hline $\begin{array}{l}\text { 12. Tecido de } \\
\text { granulaçào }\end{array}$ & $\begin{aligned} 1= & \text { Pele integra ou ferida de espessura parcial } \\
2= & \text { Vermelho vivo brilhante; } 75 \% \text { a } 100 \% \text { da ferida preenchida e/ou } \\
& \text { crescimento excessivo de tecido } \\
3= & \text { Vermelho vivo brillhante: }<75 \% \text { e }>25 \% \text { da ferida preenchida } \\
4= & \text { Róseo e/ou vermelho escuro opaco e/ou preenche }<25 \% \text { da ferida } \\
5= & \text { Auséncia de tecido de granulaçăo }\end{aligned}$ & & & \\
\hline 13. Epitelizaçào & $\begin{aligned} 1= & 100 \% \text { da ferida coberta, superficie intacta } \\
2= & 75 \% \text { a }<100 \% \text { da ferida coberta e } / \text { ou com tecido epitelial } \\
& \text { estendendo-se }>0,5 \mathrm{~cm} \text { no leito da ferida } \\
3= & 50 \% \text { a }<75 \% \text { da ferida coberta e } / \text { ou com tecido epitelial } \\
& \text { estendendo- } 5 \mathrm{e}<0,5 \mathrm{~cm} \text { no leito da ferida } \\
4= & 25 \% \text { a }<50 \% \text { da ferida coberta } \\
5= & <25 \% \text { da ferida coberta }\end{aligned}$ & & & \\
\hline \multicolumn{2}{|r|}{ PONTUACXÃO TOTAL } & & & \\
\hline
\end{tabular}

\section{REGISTRO DE AVALIAÇÃO DA FERIDA}

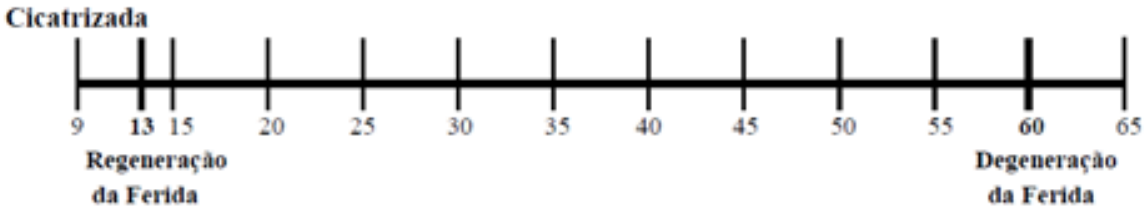

Assinale com um " $\mathrm{X}$ " a pontuação total na linha do Registro de Avaliação da Ferida, inserindo a data abaixo da linha. Anote as diversas pontuaçòes e suas respectivas datas, a fim de possibilitar uma rápida visualizaçằo da regeneraçào ou degeneraçăo da ferida. 